Supporting Information

\title{
Preparation of 4-Allylisoindoline via a Kumada Coupling with Allylmagnesium Chloride
}

\author{
Michael J. Zacuto, * C. Scott Shultz, and Michel Journet \\ Department of Process Research. Merck and Co., Inc. P.O. Box 2000 Rahway, NJ 07065 \\ michael_zacuto@merck.com
}

Table of Contents

General Methods.....................S1

Experimental Procedure and Characterization Data for $\mathbf{1} \cdot \mathbf{H C l} \ldots \ldots \ldots \ldots \ldots \ldots . . .52-3$

Experimental Procedure and Characterization Data for $3 \bullet \mathbf{H C l} \ldots \ldots \ldots \ldots \ldots \ldots . . .54$

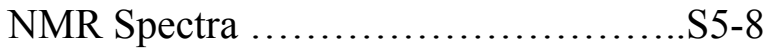

\section{General Methods}

Reagents and solvents were obtained from commercial sources and were used as received. Chromatography was performed using silica gel (70-230 mesh), using reagent grade solvents which were used as received. ${ }^{1} \mathrm{H}$ NMR spectra were recorded at $400 \mathrm{MHz}$ using Bruker Avance 400 NMR spectrometers unless otherwise noted, using the $d_{6}$-dmso resonance as an internal standard measured at $2.50 \mathrm{ppm} .{ }^{13} \mathrm{C}$ NMR spectra were recorded on 100 or $125 \mathrm{MHz}$ using Bruker Avance NMR spectrometers unless otherwise noted, using the $d_{6}$-dmso resonance as an internal standard measured at $39.5 \mathrm{ppm}$. All manipulations were carried out under an inert atmosphere of nitrogen using standard Schlenk techniques unless otherwise noted. Allyl- $\mathrm{MgCl}$ was purchased from Acros and was used as received. $\mathrm{Pd}(\mathrm{OAc})_{2}$ and (neopentyl $)\left(t-\mathrm{Bu}_{2}\right) \mathrm{P} \cdot \mathrm{HBF}_{4}$ were purchased from Strem Chemicals and used as received. All other reagents were purchased from Aldrich Chemical Co. unless otherwise noted. 
4-Allylisoindoline•HCl. A 3 L flask equipped with overhead stirring, an addition funnel and a thermocouple was purged with $\mathrm{N}_{2}$, then charged under positive $\mathrm{N}_{2}$ pressure with $\quad 2 \cdot \mathbf{H C l} \quad(100 \quad \mathrm{~g}, \quad 0.426 \mathrm{~mol}), \quad \operatorname{Pd}(\mathrm{OAc})_{2} \quad\left(\begin{array}{lllll}0.48 & \mathrm{~g}, & 2.13 & \mathrm{mmol}\end{array}\right)$ and (neopentyl) $t \mathrm{Bu}_{2} \mathrm{P} \cdot \mathrm{HBF}_{4}(1.3 \mathrm{~g}, 4.3 \mathrm{mmol})$. The flask was then charged with toluene (1.8 L, which had been previously de-oxygenated via $\mathrm{N}_{2}$ subsurface sparging). Allylmagnesium chloride ( $800 \mathrm{~mL}, 1.36 \mathrm{~mol}, 1.7 \mathrm{M}$ in THF) was charged to the addition funnel and then added to the slurry, with external cooling, over $1 \mathrm{~h}$ such that $\mathrm{T}_{\mathrm{i}} \leq 25^{\circ} \mathrm{C}$. ${ }^{1}$ The resulting solution was then heated to and maintained at $\mathrm{T}_{\mathrm{i}}=45-50{ }^{\circ} \mathrm{C}$ for $16 \mathrm{~h}$. After cooling to ambient temperature, the reaction was inverse-quenched by slow transfer, with external cooling and at a rate such that $\mathrm{T}_{\mathrm{i}}<35^{\circ} \mathrm{C}$, into a $3 \mathrm{~L}$ jacketed flask (equipped with a drop valve and overhead stirring) that had been charged with a solution of $15 \mathrm{wt} \%$ citric acid $(1.1 \mathrm{~L})$. The organic phase, which contained $1.2 \mathrm{~g}$ of $\mathbf{1}$ by assay, was rejected. The aqueous phase was assayed for $61.3 \mathrm{~g}$ of 1 (90\% yield in organic phase, corresponding to a $92 \%$ end of reaction assay yield, along with $2.6 \%$ AY of 3 ). The aqueous phase was transferred to an extractor, to which was charged fresh toluene (650 $\mathrm{mL})$ and the resulting biphasic mixture was stirred. Ammonium hydroxide $(28-30 \%$ in water, $650 \mathrm{~mL}$ ) was added at a rate such that $\mathrm{T}_{\mathrm{i}} \leq 30^{\circ} \mathrm{C}$, resulting in a $\mathrm{pH} 10$ aqueous phase. The phases were separated, and the aqueous phase (which contained $1.8 \mathrm{~g}$ of $\mathbf{1}$ by assay, $1.0 \mathrm{~g} / \mathrm{L})$ was extracted with $200 \mathrm{~mL}$ of toluene $(0.3 \mathrm{~g}$ of 1 remained in the aqueous phase after extraction, or $0.18 \mathrm{~g} / \mathrm{L}$ ). The combined organic phases were then washed with $160 \mathrm{~mL}$ of $15 \mathrm{wt} \%$ aqueous $\mathrm{NaCl}$. The toluene solution was dried via azeotropic distillation with toluene under "constant volume" conditions, then concentrated to a 650

\footnotetext{
${ }^{1}$ Evolution of propene occurs during the exothermic addition of allylmagnesium chloride at a rate proportional to the rate of addition. A mild $\mathrm{N}_{2}$ sweep efficiently removed any residual propene that was observed to evolve upon heating to $\mathrm{T}_{\mathrm{i}}=45^{\circ} \mathrm{C}$.
} 
$\mathrm{mL}$ total volume solution $\left(\mathrm{KF}=500 \mathrm{ppm} \mathrm{H}_{2} \mathrm{O}\right)$. The solution was assayed by $\mathrm{wt} / \mathrm{wt} \%$ to contain $59.4 \mathrm{~g}$ of $\mathbf{1}(87.5 \% \mathrm{AY}$ after workup).

The toluene solution of $\mathbf{1}$ was transferred to a $1 \mathrm{~L}$ flask equipped with overhead stirring, an addition funnel and a thermocouple. A solution of $\mathrm{HCl}$ in $i \mathrm{PrOH}(5.1 \mathrm{M})$ was transferred to the addition funnel, and then added slowly over 1 hour to the solution of $\mathbf{1}$ in toluene, at a rate such that $\mathrm{T}_{\mathrm{i}} \leq 40^{\circ} \mathrm{C}$. The resulting slurry was aged for 6 hours, with gradual cooling to ambient temperature. The slurry was then slowly cooled to $\mathrm{T}_{\mathrm{i}}=0{ }^{\circ} \mathrm{C}$ over 1 hour, then maintained at this temperature for an additional hour. The slurry was filtered, with loss to the supernatant assayed at $7.6 \mathrm{~g} / \mathrm{L}$ of $\mathbf{1} \cdot \mathbf{H C l}(4.12 \mathrm{~g}$ total, along with $1.6 \mathrm{~g}$ of $3 \cdot \mathbf{H C l}$ ). The cake was washed with $175 \mathrm{~mL}$ of 9:1 toluene:IPA (pre-cooled to $\mathrm{T}_{\mathrm{i}}$ $=0{ }^{\circ} \mathrm{C}$ ), then dried with vacuum $/ \mathrm{N}_{2}$ sweep. 1•HCl was isolated as an off white solid $(69.5 \mathrm{~g})$ that was assayed at $96 \mathrm{wt} \%$ (97.6 area \% by HPLC), corresponding to an isolated yield of $80 \%$. ${ }^{1} \mathrm{H}$ NMR (400 MHz, $d_{6}$-dmso) $\delta 9.95$ (br s, 2H), $7.32(\mathrm{t}, J=7.4 \mathrm{~Hz}, 1 \mathrm{H})$, $7.25(\mathrm{~d}, J=7.4 \mathrm{~Hz}, 1 \mathrm{H}), 7.16(\mathrm{~d}, J=7.4 \mathrm{~Hz}, 1 \mathrm{H}), 5.96-5.84(\mathrm{~m}, 1 \mathrm{H}), 5.10-5.04$ (om, 2H), $4.48(\mathrm{~s}, 2 \mathrm{H}), 4.45(\mathrm{~s}, 2 \mathrm{H}), 3.37(\mathrm{~d}, J=6.5 \mathrm{~Hz}, 2 \mathrm{H}) ;{ }^{13} \mathrm{C} \mathrm{NMR}\left(100 \mathrm{MHz}, d_{6}\right.$-dmso) $\delta$ $135.6,135.1,134.6,133.8,128.7,128.3,120.8,116.4,49.8,48.7,36.9 ;$ HRMS $[\mathrm{M}+\mathrm{H}]^{+}$ for $\mathrm{C}_{11} \mathrm{H}_{13} \mathrm{~N}$ calc'd 160.1126 , found 160.1128 . 


\section{Compound 3:}

The identity of $\mathbf{3}$ was initially determined using LCMS. In an effort to independently verify the structure, an authentic sample was prepared from pure $\mathbf{1}$.
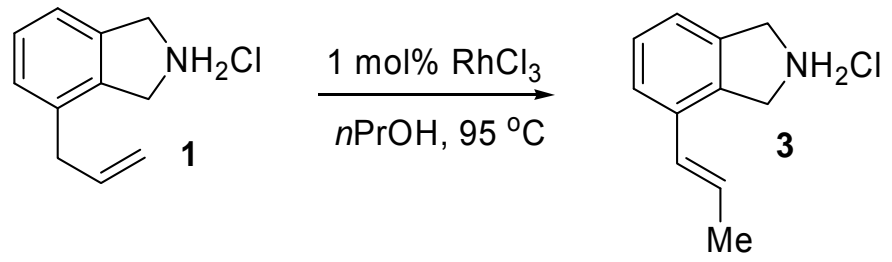

A flask was charged with $\mathbf{1} \cdot \mathbf{H C l}$ salt $(0.5 \mathrm{~g}, 3.14 \mathrm{mmol})$ and $\mathrm{RhCl}_{3}$ hydrate $(6 \mathrm{mg}$, $0.03 \mathrm{mmol})$, then $n \mathrm{PrOH}(15 \mathrm{~mL})$. The flask was sealed under an $\mathrm{N}_{2}$ atmosphere and heated to $\mathrm{T}_{\mathrm{i}}=95{ }^{\circ} \mathrm{C}$ for $10 \mathrm{~h}$. The solution was gradually cooled to ambient temperature, whereupon a slurry formed. The product was filtered, and the cake was washed with $n$ PrOH. Drying afforded $300 \mathrm{mg}$ of $3 \cdot \mathbf{H C l} .{ }^{1} \mathrm{H}$ NMR $\left(400 \mathrm{MHz}, d_{6}\right.$-dmso) $\delta 9.56$ (br s, 2H), 7.45 (d, $J=7.7 \mathrm{~Hz}, 1 \mathrm{H}), 7.32$ (t, $J=7.7 \mathrm{~Hz}, 1 \mathrm{H}), 7.24$ (d, $J=7.7 \mathrm{~Hz}, 1 \mathrm{H}), 6.44$ (dd, $J=15.8,1.5 \mathrm{~Hz}, 1 \mathrm{H}), 6.29(\mathrm{dq}, J=15.8,6.6 \mathrm{~Hz}, 1 \mathrm{H}), 4.53(\mathrm{~s}, 2 \mathrm{H}), 4.47$ (s, 2H), 1.89 (dd, $J=6.6,1.5 \mathrm{~Hz}, 3 \mathrm{H}) ;{ }^{13} \mathrm{C} \mathrm{NMR}\left(125 \mathrm{MHz}, d_{6}\right.$-dmso) $\delta 135.5,132.6,131.8,128.8,128.6$, 127.6, 124.6, 121.1, 49.8, 49.3, 18.5; HRMS $[\mathrm{M}+\mathrm{H}]^{+}$for $\mathrm{C}_{11} \mathrm{H}_{13} \mathrm{~N}$ calc'd 160.1126, found 160.1130 . 
F2 - Acquisition Parameters
Date_

Time-

INSTRUM
PROBHD $5 \mathrm{~mm}$ QNP $\begin{gathered}11.13 \\ \text { spect } \\ 1 \mathrm{H} / 1\end{gathered}$

PUIPROG
TD
Pg

TD
SOLVENT

DS

SWH
FIDRES
6561.680
0.20072

$\begin{array}{lr}\text { FIDRES } & 0.200247 \mathrm{~Hz} \\ \text { AQ } & 2.4970479 \mathrm{sec} \\ \text { RG } & 406.4\end{array}$

$\begin{array}{rr}\text { RG } & 406.4 \text { usec } \\ \text { DW } & 76.200 \text { usec } \\ \text { DE } & 7.000 \text { usec }\end{array}$

$300.2 \mathrm{~K}$

TDO 1

$=======$ CHANNEL $\mathrm{f} 1=======$
NUC1
$1 \mathrm{H}$

$\begin{array}{lr}\text { N1 } & 1 \mathrm{H} \text { usec } \\ \text { PL1 } & 9.40 \text { usec }\end{array}$

SFO1 $400.1324710 \mathrm{MHz}$

F2 - Processing parameters

SI $\quad 400.1300022 \mathrm{MHz}$

$\begin{array}{lc}\text { WDW } & \text { EM } \\ \text { SSB } & 0 \\ \text { LB } & 0.30 \mathrm{~Hz} \\ \text { GB } & 0 \\ \text { PC } & 1.00\end{array}$
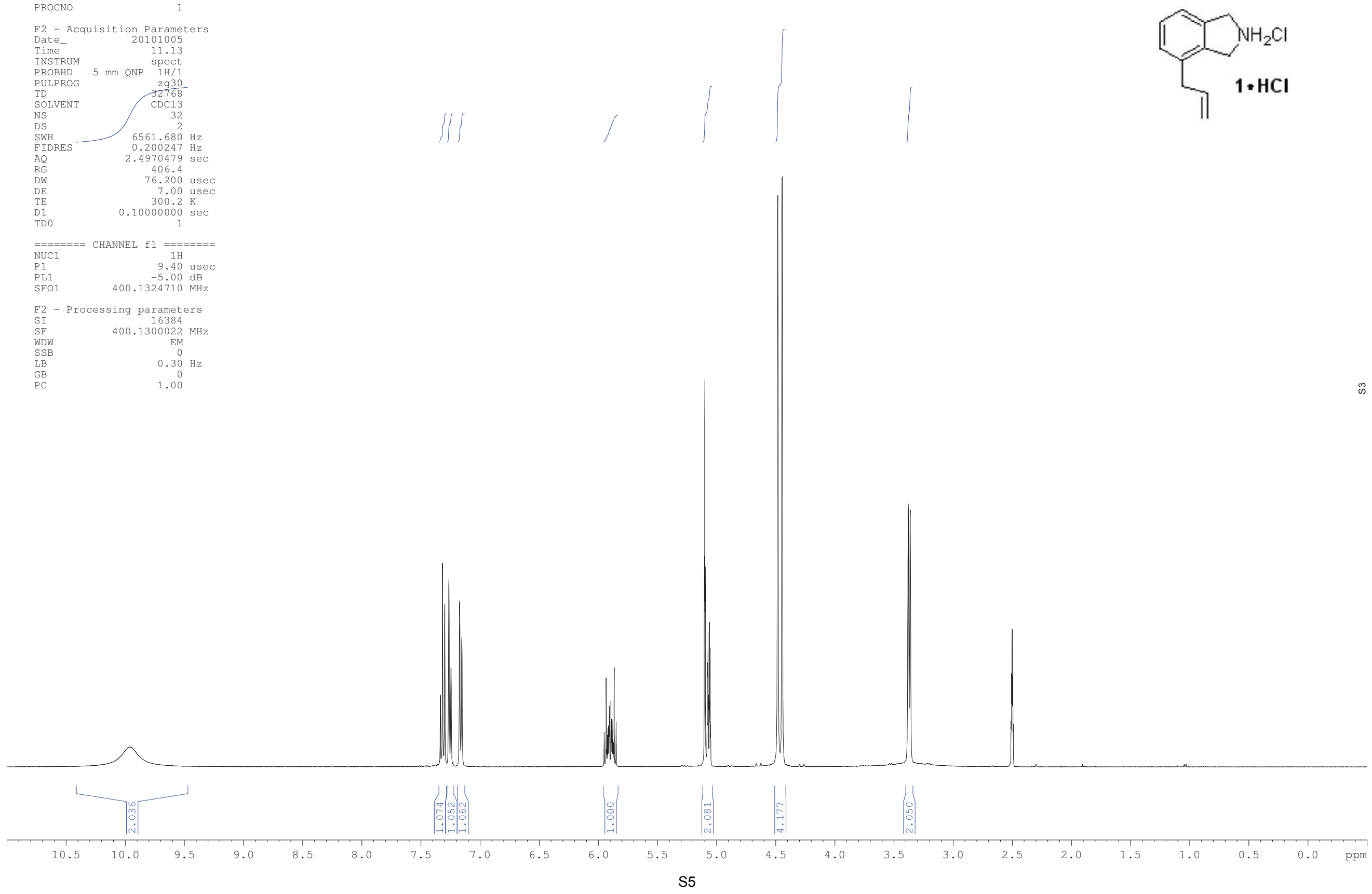

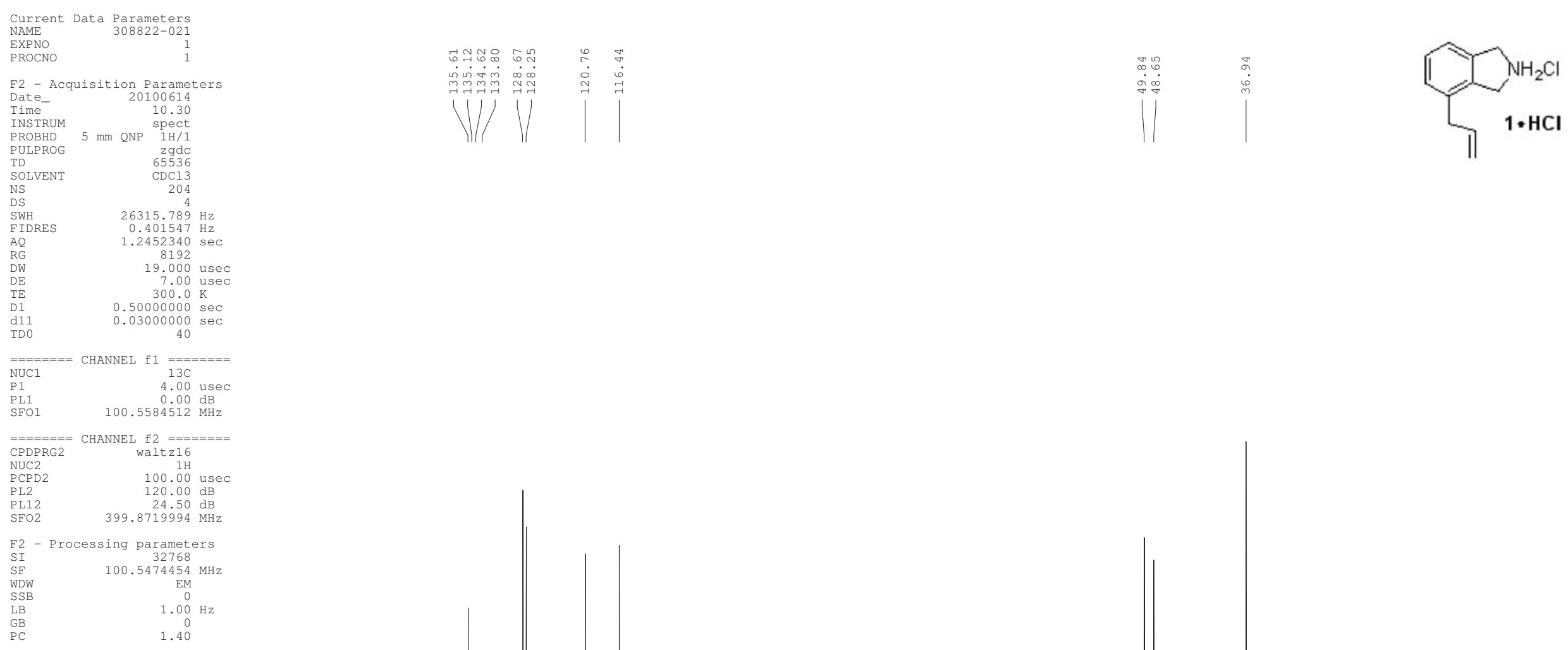

$$
1.40
$$


styrene $\mathrm{HCl}$ salt $1 \mathrm{H}$ NMR (400 MHz, d6-dmso)
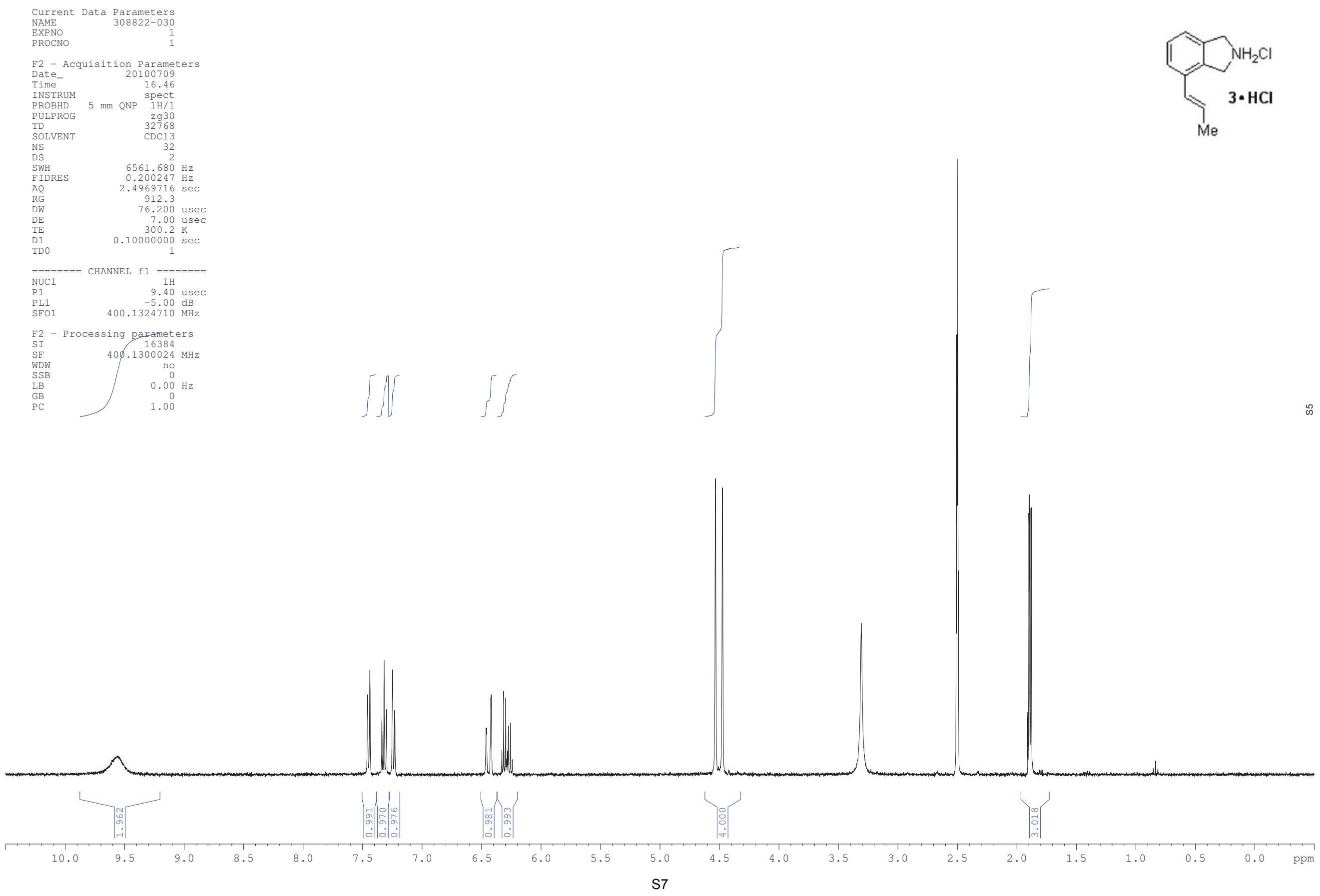


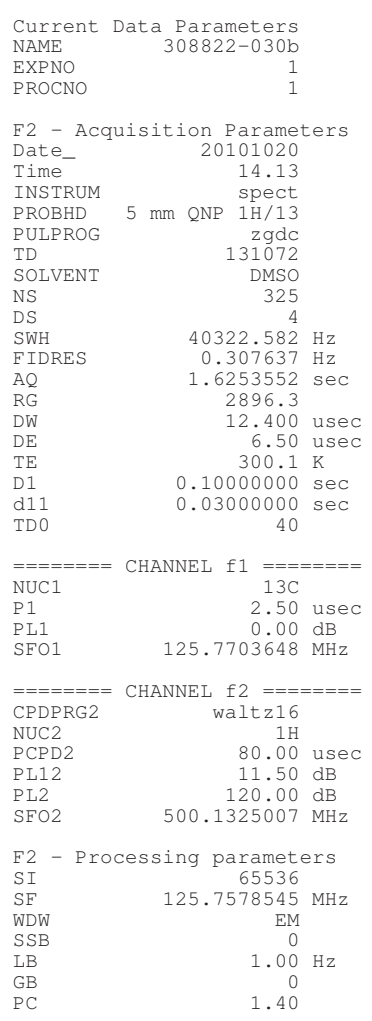

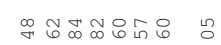

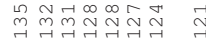

$|N|||$

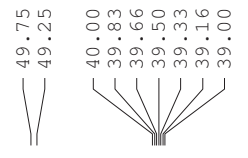

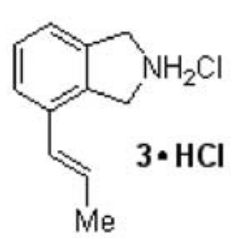

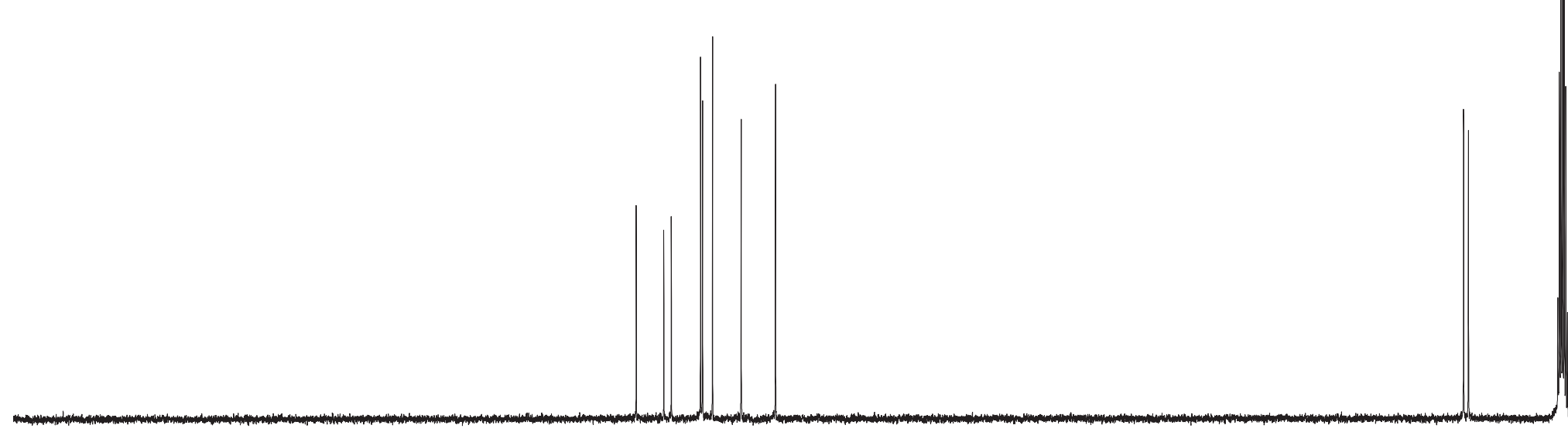

